\title{
審査官による先行技術文献調査と無料で使える ユニークなデータベースの活用法
}

\section{小川裕子1}

著者抄録 : 三極特許庁（日本, 米国, ヨーロッパ等）の審査官による先行技術調査について, 使用し ている各種のデータベース, 検索に用いる切り口 (例えば, 分類の種類やキーワード等), 調査対象 国, 調査対象情報 (例えば, 特許や非特許文献), 検索範囲（例えば, データベースか検索エンジン を用いたインターネットからの情報も含めるか) 等について比較している。また, 出願人が先行技 術調査に使える無料でユニークなデータベースや, 各国特許庁が提供しているデータベースの無料 調査マニュアルを作成しているサイト等を紹介している。

キーワード : 先行技術調査, 番査戻し, 引用文献, 審査官, インターネット, サーチエンジン, 証拠 能力, JOPAL, 全文検索, esp@cenet, epoline, 電子包袋, DB航海士, 韓国特許情報院, 中華民国 専利資訊網

\section{Prior art literature search by patent examiners, and use method of unique databases available on the Web free of charge}

\section{OGAWA Yuko'}

\begin{abstract}
Author Abstract: The author deals wish prior art search by examiners affiliated with three major patent offices (Japan, US and Europe). She compares search means being employed by those examiners among those patent offices in terms of various databases, search tags (classification type, keywords, for instance), nations covered in the prior art search, information covered in the search (patents, non-patent literature, for instance), search range covered (databases, information available on the Internet through search engines, so on). The author also introduces unique databases available free of charge, which applicants are allowed to use for their prior art search, and web sites availing free of charge examination manuals of databases which the Patent Offices are providing.
\end{abstract}

Key words: prior art search, examination drawback, cited literature, examiner, Internet, search engine, evidence capacity, JOPAL, full text search, esp@cenet, epoline, digital patent documents file, DB Navigator, Korean Institute of Patent Information, Taiwan Patent Net

\section{1.はじめに}

最近の拒絶理由通知に付与される引用文献数は 以前と比較すると,かなり多くなっていると思う。 また, 審査時の審査戻し件数はかなり増加して いるそうである。審査戻しが多いという理由のひ とつとして出願時の出願人による先行技術調査が 不足していることが原因とされ, 特許庁は 2002 年 9
月1日に「先行技術文献開示制度」を施行している。 出願人の先行技術調査が不足していると考えられ た背景には, 出願時に明細書に公開している先行 技術文献と審査時調査で発見される先行技術文献 が大きく異なるからだと思われる。

そのような理由であれば, 審査時調査で引用さ れるような文献を出願時に明細書に公開しておけ ば審査はスムーズに行われるということになる。

1オルガノ株式会社＼cjkstart法務特許部（†136-8631 東京都江東区新砂1-2-8）

Tel.03(5635)5122 E-mail: ogawa-yk@organo.co.jp ogawa-yu@joy2.tvnet.ne.jp

${ }^{1}$ Legal \& Patent Dept, Organo Corporation (2-8, Shinsuna-1chome, Koto-ku, Tokyo, 136-8631) 
このような出願人と審査官の引用文献の相違が 増加した背景には, 審査官が以前に比べて審査時 調査を充実させているからではないかと思われる。

そこで, 実際に審査官がどのような調査を行っ ているのかを審査例から三極の調査状況を比較し てみたい。それを知る事で出願側の先行技術調査 を充実させ,スムーズな審査をしていただき, 早 期権利化を目指したいと思う。

また, 最近, 各国特許庁や各機関において先行 技術調査にも役立つ各種データベースが無料で提 供されている。その一部を 2003 年1月号から 3 月号 の「情報管理」へ連載したが, 最近の各国特許庁 の動きは非常に早く, すでにデータ更新した部分 や新規に追加された部分がある。それらについて は私が個人的に作成している「DB航海士」を見て 頂ければ最新情報を入手できると思う (http://www2. tky.3web.ne.jp/ infosta/ougpat/simpo/)。

今回は, 前回の拙著者の記事で紹介していない データベースで, 商用データベースにはない機能 をもったユニークなもので先行技術文献調査に役 立つ非特許情報が収録されている無料のデータベー スや, 検索結果を無料でダウンロードできるデー タベース等の活用法を紹介したい。

\section{2. 先行技術文献情報開示制度について}

ここでは研究者・技術者のために簡単に説明す る。この制度により出願人は出願時に知っている 文献公知発明に関する情報を開示する義務を負う こととなる (特許法 第36条第4項第2号)。

また, その義務を忿った以下のような場合, 審 査官はそれを拒絶理由とすることが可能となる (特 許法 第48条第7項)。

口公知番号の記載がなく, その理由が記載されて いない

口 公知番号の記載はないが, 理由は記載されてい る, しかし関連のある公知文献を出願人が知っ ている蓋然性が高い

口 従来技術が明細書中に記載されているのに, 公 知文献の番号が記載されていない

口公知番号の記載はあるが, もっと関連性の高い 公知文献が存在する蓋然性が高い

太原則としては公知番号の記載がなくても拒絶理 由は通知されないが, 悪質であると判断された 場合と過去に何度も 48 条の7の通知がされてい る場合, 拒絶理由の対象となることがある。 上記のような事から, 審査をスムーズに通すた
めにも, 出願時の先行技術調査はしっかり行い, 知りえたものは出願時にできる限り記載した方が 良いと思う。

\section{3. 日米欧の審査時調査比較}

ここでは審査官が審査時調査においてどのよう なデータベースを用いて, どのような調査を行っ ているのかを日本, 米国, 欧州において比較表を 作成し, 使用しているデータベースや検索対象と なる情報 (非特許文献も含む), さらに, 調査に用 いる特許分類等について, その違いや共通点を確 認した（表1）。

JPO (日本特許庁) : 国際分類やFI, Fターム等の日 本分類,さらにUSC (米国特許分類),ECLA (European Patent Classification欧州特許分類）等の各国分類を よく用いて調査している(分類重視)

商用データベースではダウエントのWPI (World Patent Index世界中の特許を収録）を使用

ロ インターネット上のサーチエンジンを用いて非 特許文献を調査

—CSDB（Computer Software Database）を用いた調 査も行う

一検索対象特許は日本と米国特許が半々

USPTO (米国特許庁) : 分類は主に自国のUSCを使 用している

ロ 商用データベースではDIALOG とSTNを使用

ロ インターネット上のサーチエンジンを用いて非 特許文献を調査

- 検索対象特許は $80 \%$ が米国特許

EPO (欧州特許庁) : 分類は主にECLAを使用している 商用データベースではINSPEC (物理, 気工学等の 世界中の文献を収録）を使用

ロ インターネット上のサーチエンジンを用いて非 特許文献を調査

— 検索対象特許は米国特許とPCT (Patent Cooperation Treaty）出願を中心に調査している これらの比較においては対象がビジネスモデル 特許ということもあり, 検索対象特許の比率が米 国が多いのは当然のことである。

しかし, どのようなデータベースを用いた調査 を行っているのかということはわかった。これら のデータベースがいつでも使える環境が整ってい るということであり, いずれの調査の時にも使え るということである。

審査官が使用しているデータベースは下記の 4 種 であった。 
表1 三極における審査比較（例：ビジネスモデル特許）

\begin{tabular}{|c|c|c|c|}
\hline 調査内容 & JPO（日本特許庁） & USPTO（米国特許庁） & EPO（欧州特許庁） \\
\hline 国内調査 & 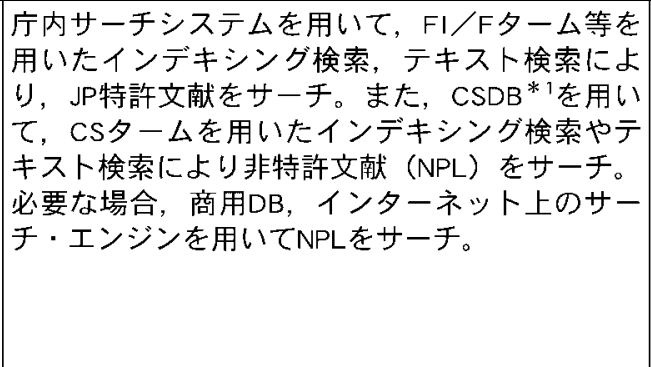 & $\begin{array}{l}\text { 庁内サーチシステムを用い } \\
\text { て, USCを用いたインデキシ } \\
\text { ング検索, テキスト検索によ } \\
\text { り, US特許文献をサーチ。 } \\
\end{array}$ & 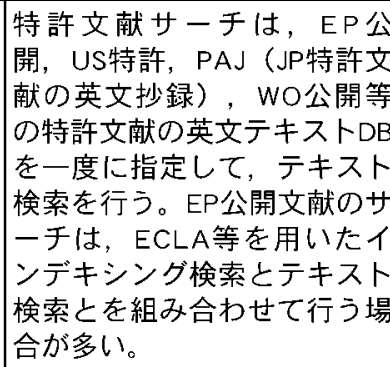 \\
\hline $\begin{array}{c}\text { 外国調査 } \\
\text { (1) }\end{array}$ & $\begin{array}{l}\text { 必要な場合, 更に, US特許, EP公開文献を，そ } \\
\text { れぞれ，USC (米国特許分類)，ECLA（欧州特 } \\
\text { 許分類）等を用いたインデキシング検索，テキス } \\
\text { ト検索によりサーチ。他の外国特許文献（WO公 } \\
\text { 開文献等）のサーチには，WPIを主に使用。 }\end{array}$ & $\begin{array}{l}\text { 必要な場合, DIALOG, STN, } \\
\text { インターネット上のサーチ. } \\
\text { エンジンを主に使用して非特 } \\
\text { 許文献(NPL) をサーチ。 }\end{array}$ & $\begin{array}{l}\text { 必要な場合, 更に, INSPEC, } \\
\text { インターネット上のサーチ． } \\
\text { エンジンを用いて, 非特許文 } \\
\text { 献 (NPL) をサーチ。 }\end{array}$ \\
\hline $\begin{array}{c}\text { 外国調查 } \\
\text { (2) }\end{array}$ & & $\begin{array}{l}\text { EP公開文献, PAJ（JP特許文 } \\
\text { 献の英文抄録）等を含む複数 } \\
\text { の特許文献の英文テキストDB } \\
\text { を一度に指定して外国特許文 } \\
\text { 献をサーチ。 }\end{array}$ & \\
\hline $\begin{array}{c}\text { 調査対象 } \\
\text { 特許 }\end{array}$ & $\begin{array}{l}\text { JP特許文献が半数以上（53\%），外国特許文献の } \\
\text { ほとんどはUS特許文献。NPLについては，提示 } \\
\text { 数，割合ともに，他庁を上回る。 }\end{array}$ & $\begin{array}{l}\text { US特許文献の割合は80\%以 } \\
\text { 上。WO公開文献等の外国特 } \\
\text { 許文献は主にDIALOGやSTNを } \\
\text { 利用して発見。 }\end{array}$ & $\begin{array}{l}\text { US特許文献 }(50 \%) \text { とWO公 } \\
\text { 開文献 }(36 \%) \text { の割合が他の } \\
\text { 文献種別より高い。NPLの- } \\
\text { 部はインターネットを用いて } \\
\text { 発見。 }\end{array}$ \\
\hline
\end{tabular}

* $1:$ CSDBtとはコンピュータソフトウエアデータベースのことで平成15年度より特許電子図書館より一般に公開されている （公開前は審査官が審査を行うための庁内データベースであった）CSタームも同時に公開された）

(1) 自国所有のデータベース

(2) 他庁が提供しているデータベース

(3) 各種商用データベース

(4) インターネットのサーチエンジンを用いた非特 許文献 (NPL (Non-patent Literature)）調査 ここで気になったのは(4)の調査についてである。 ではなぜこのような調査がなされるのかといえ ば，それは，インターネット上で配信されている 文献に証拠能力が認められたからだと思う。

「インターネット等の情報の先行技術としての取 り扱い運用指針」は2000年1月1日より施行されて いる。

特許法第二十九条第一項 (抜粋)

産業上利用することができる発明をした者は、 次に揭げる発明を除き，その発明について特 許を受けることができる。

... .

三 特許出願前に日本国内又は外国において、 頒布された刊行物に記載された発明又は電気 通信回線を通じて公衆に利用可能となった発明
電気通信回線を通じた発表行為を証明する書面 については以下のような書類が必要となる。

1. 電気通信回線を通じた発表行為を証明する書面 には,その情報の内容,その情報を発表したホー ムページ等のプリントアウト, その情報の掲載 日時の表示, 発表者, その情報を掲載したアド レスが含まれる必要がある。 その際，その情報に関して掲載，保全等に権限 または責任を有する者による証明書類を添付す ることが望ましい。

2. 提出された電気通信回線を通じた発表行為を証 明する書面に疑義があると判断した場合には, 審査官は, 問い合わせ先等に表示されている連 絡先に, 改変されているか否かの照会をする。 疑義が解消しない場合には, その旨を拒絶理由 通知等で指摘する。

今まで, 企業における先行技術調査といえば, 自社所有のデータベースや各種商用データベース, また電子公報や紙公報による調査が主体であり， インターネット上から自由自在に提供されている 情報については調査対象外であった。しかし, 今 後は三極審査官と同様にインータネットのサーチ 
エンジンを用いた非特許文献の調査も行う必要が あるということになると思う。

また，(3)にもあるように, さまざまの商用デー タベースを用いて, 特許のみならず非特許文献も 検索しているようである。このような調査は以前 の審査時調査においてはされていなかったように 思う。各国の特許庁内で使用可能なデータベース の環境整備がかなりすすんでいると思われる。と いうことは, 出願人も出願前の先行技術文献調査 をしっかり行わないと, さらに多くの拒絶理由通 知や引用文献が届くことになる。

\section{4. 各国特許庁や各機関から提供されて いるユニークなデータベースの活用 法}

JPO, USPTO, EPO, WIPO (World Intellectual Property Organization）等の審査官は審査時, 相互 に他庁から提供されているデータベースを使って いる。日本特許庁が提供しているIPDL (Industrial Property Digital Library)については周知であると思 うので, その他の庁がどのようなデータベースを 提供しているのかを見てみたい（表2）。

これらのデータベースの中にはとてもユニーク なものがある。そのひとつがWIPOが提供している JOPAL (Journal of Patent Associated Literature) とい うデータベースである。これは, IPC（国際特許分 類）で非特許文献が検索できる。商用データベー スではCAS（米国化学会）が提供しているデータ ベースが特許と非特許文献を両方収録し,キーワー ド等で双方を同時に検索可能であるが, IPCで検索 可能なのは収録されているデータのうち特許のみ であり, 非特許文献にIPCが付与されているわけで はない。

ここがJOPALとの大きな違いである。JOPALの場 合はIPCで非特許文献と特許を同時に検索すること ができる。もちろんキーワードからの検索も可能 であるし, IPCとキーワードの演算や収録文献を指 定した検索も可能である。しかも無料であり, 検 索された特許については全文をテキストでも公報 イメージとしても取得可能である。検索された非 特許文献（科学技術雑誌）については抄録等を見 ることはできないが, 書誌事項が表示されるので, 後から原文等を別のルートで取得することも可能 である。

先行技術調査は特許と非特許文献のいずれも調 査対象であり，これらが同時にしかも無料で検索

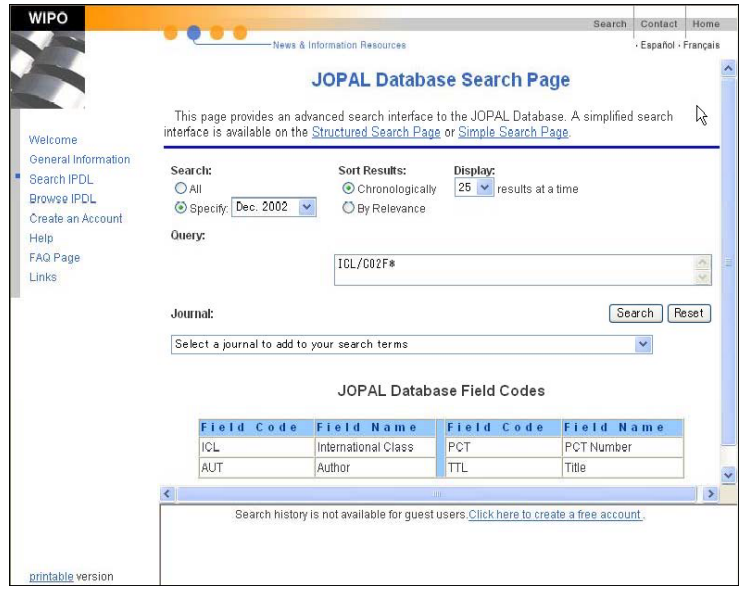

図1 JOPAL検索画面 WIPOより

できる（図1，2，3，4，5）。

つまりユーザにとって，コスト削減と検索時間 の短縮ができ, 非常に便利である。

口収録期間 : 1981-2002/12（2003/7現在）

—収録情報：主要な科学技術の定期刊行物の中で 公表された記事の著書目録の詳細

ロソート順：年代順 OR 関連順

表示件数 $10 ， 25 ， 50$ （デフォルト25）

検索可能項目 :

(1) IPC（国際特許分類）

(2) 著者

(3) 収録雑誌 $N 0$.

(4) タイトルからのキーワード検索

収録雑誌の選択 : 231誌から選択可能

検索コマンド

OR, AND, ANDNOT, XOR, NEAR, *がある $\mathrm{ANDNOT}=\mathrm{A}$ はあるがBが存在しないもの $\mathrm{XOR}=\mathrm{A}$ もしはBがあるが両方が共存しないも の

$\mathrm{NEAR}=$ 隣接する 20 文字以内にAとBがあるもの *=ワイルドカードとなる

図1で検索した結果が図2である。

図2のJOPAL検索結果に表示される項目一覧。

表示項目
(1) IPC
(2) 著者
(3) タイトル
(4) PCTの雑誌番号
(5) 発行年
(6) 巻
(7) 号
(8) 開始ページ 
解説 @審査官による先行技術文献調査と無料で使えるユニークなデータベースの活用法

表2 世界知的所有権機関と三極特許庁提供のデータベースー覧

\begin{tabular}{|c|c|c|c|}
\hline $\mathrm{CN}$ & 提供データベース一覧 & 収録期間 & 収録内容 \\
\hline \multirow{7}{*}{$\begin{array}{l}\text { W } \\
1 \\
P \\
O\end{array}$} & PCT Electronic Gazette & 1997/1- & $\begin{array}{l}\text { 検索対象は登録および公開特許の書誌，抄録 } \\
\text { ネ全文公報イメージ出力可能 }\end{array}$ \\
\hline & $\begin{array}{l}\text { PCT Full Text Database } \\
\text { Prototype（試験運用中） }\end{array}$ & $2003 / 1-$ & $\begin{array}{l}\text { テキスト全文が収録されているので全文検索可能 } \\
\text { ネ全文公報イメージ出力可能 }\end{array}$ \\
\hline & Madrid Express Database & \begin{tabular}{|l} 
現在有効な国際登録商標すべてと商標 \\
過去6ヶ月以内に終了した部
\end{tabular} & 登録商標 \\
\hline & - Hague Express & $\begin{array}{l}\text { 1999年のNo.1から収録（1999年の } \\
\text { ヘーグ協定に基づいて出願された } \\
\text { 意匠） }\end{array}$ & 登録意匠 \\
\hline & $\begin{array}{l}\text { Health Heritage Test } \\
\text { Database (試用版) }\end{array}$ & 健康遺産CD-ROM権利消滅したもの & $\begin{array}{l}\text { インド政府が収集した健康遺産となり得る権利消滅 } \\
\text { した特許 }\end{array}$ \\
\hline & 口 JOPAL & $\begin{array}{l}\text { 1981年-2002年 } 12 \text { 月 } \\
\text { (2003/7現在) }\end{array}$ & $\begin{array}{l}\text { 主要な科学技術の定期刊行物の中で公表された記事 } \\
\text { の著書目録の詳細 } \\
\text { ネIPC (国際特許分類) で科学技術文献と特許を同 } \\
\text { 時に検索可能 }\end{array}$ \\
\hline & $\begin{array}{l}\text { 口IPC（国際特許分類）検 } \\
\text { 索データベース }\end{array}$ & 第7版 第6版 & れ 検索したIPCの説明文をPDFで取得可能 \\
\hline \multirow{6}{*}{$\begin{array}{l}\text { U } \\
\text { S } \\
\mathrm{P} \\
\mathrm{T} \\
\mathrm{O}\end{array}$} & D PatFT（登録特許） & $\begin{array}{l}\text { 1790-（番号検索のみ） } \\
\text { 1976-（全文検索可能） }\end{array}$ & $\begin{array}{l}\text { 登録特許 } \\
\text { 意匠 } \\
\text { 植物特許 } \\
\text { 再登録特許 } \\
\text { 防衛出願公告 } \\
\text { 防衛発明登録 } \\
\text { ^全文公報イメージ出力可能 }\end{array}$ \\
\hline & D AppFT（公開特許） & $2001 / 3 / 15 /-$ & 公開特許 太 全文公報イメージ出力可能 \\
\hline & $\begin{array}{l}\text { घUSC (米国分類) 検索 } \\
\text { データベース }\end{array}$ & $\begin{array}{l}\text { 最新USC } \\
\text { ネUCSではECLAとの統合を進めて } \\
\text { いる }\end{array}$ & $\begin{array}{l}\text { USCのキーワード検索 IPCとのコンコーダンス } \\
\star \text { すでにUSC257の中でECLA（欧州分類）との統合 } \\
\text { ができており，同一の分類内にE-SUBCLASSESが作 } \\
\text { 成させている }\end{array}$ \\
\hline & 口 PAIR（審查経過閲覧） & 1976- & $\begin{array}{l}\text { 特許および商標の経過情報とStatus情報 } \\
\text { PTA History：特許期間調整2001/5/29-（USPTO／出 } \\
\text { 願人) } \\
\text { Continuity Data：出願の継続，部分継続分割等状況 } \\
\text { Web Patent Database：全文テキストヘリンク } \\
\text { Retrieve Maint. Fee to Pay：年金オンライン支払関連 } \\
\text { View Maint. Payment Windows : 年金支払期限 } \\
\text { View Maint. Statement：年金支払状況 }(4,8,12)\end{array}$ \\
\hline & $\begin{array}{l}\text { Trademarks Electronic } \\
\text { Search System (TESS) }\end{array}$ & 登録もしくは出願中のものすべて & 現在登録もしくは公開中のもの \\
\hline & D Official Gazettes & 1964- & $\begin{array}{l}\text { Expiration of Patents（期限切れれ特許） } \\
\text { Term Extended of Patent（期間延長特許） } \\
\text { Delayed Payment of Maintenance Fee（年金の支払い } \\
\text { 遅延特許） } \\
\text { Reissue Applications Notice（再発行出願） } \\
\text { Requests for Ex Parte Reexamination（再審査請求) } \\
\text { Notice of Expiration of Registrations（登録期間満了） } \\
\text { Withdrawn patents（取下げ特許・別に一覧表あり） } \\
\text { Reclassification Alert Report（USC分類の更新） } \\
\text { その他 }\end{array}$ \\
\hline \multirow{4}{*}{$\begin{array}{l}\mathrm{E} \\
\mathrm{P} \\
\mathrm{O}\end{array}$} & D esp@cenet version3 & 表3を参照（各国別詳細） & 公開特許 登録特許 サーチレポート \\
\hline & $\begin{array}{l}\text { epoline Online European } \\
\text { Patent Register } \\
\text { epoline Online File } \\
\text { Inspection }\end{array}$ & \begin{tabular}{|l} 
全期間 \\
電子包袋は現在も遡及中で収録し \\
たものから順次提供
\end{tabular} & $\begin{array}{l}\text { 原簿情報（審査経過， status，パテントファミリー） } \\
\text { ^INPADOCのLegal status情報のすベてを掲載 } \\
\text { 電子包袋（個別でも一括でもPDFでダウンロ可 } \\
\text { 能） }\end{array}$ \\
\hline & EPO Boards of Appeal & 1979- & 審決文の全文（PDF） \\
\hline & $\begin{array}{l}\text { ECLA（ヨーロッパ特許 } \\
\text { 庁分類）検索データベース }\end{array}$ & 最新ECLA & $\begin{array}{l}\text { キーワード検索も可能 } \\
\text { ネ検索した結果を自動的に公報検索式に置換 }\end{array}$ \\
\hline
\end{tabular}


表3esp@cenetの各国別収録期間

\begin{tabular}{|c|c|c|c|c|c|c|c|c|c|c|c|}
\hline 国 & $\begin{array}{l}\text { 書誌事項 } \\
\text { データ収 } \\
\text { 録期間 }\end{array}$ & $\begin{array}{c}\text { 抄録の } \\
\text { 収録期間 }\end{array}$ & $\begin{array}{c}\text { 公報イメージ } \\
\text { 収録期間 }\end{array}$ & $\begin{array}{c}\text { IPC } \\
\text { 収録期間 }\end{array}$ & \begin{tabular}{|c|} 
ECLA \\
収録期間
\end{tabular} & 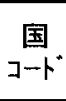 & $\begin{array}{c}\text { 書誌事項 } \\
\text { データ収 } \\
\text { 録期間 }\end{array}$ & $\begin{array}{c}\text { 抄録の } \\
\text { 収録期間 }\end{array}$ & \begin{tabular}{|c} 
公報イメージ \\
収録期間
\end{tabular} & $\begin{array}{c}\text { IPC } \\
\text { 収録期間 }\end{array}$ & $\begin{array}{c}\text { ECLA } \\
\text { 収録期間 }\end{array}$ \\
\hline $\mathrm{AP}$ & 最初から & 最初から & 最初から & 最初から & & $\mathrm{KE}$ & $1975 \sim$ & なL & なL & 1975 & \\
\hline $\mathrm{AR}$ & $\begin{array}{l}1973 \sim \\
1991 \\
\end{array}$ & なし & なし & $1975 \sim$ & & $\mathrm{KR}$ & $1978 \sim$ & $1979 \sim$ & なし & $1979 \sim$ & \\
\hline AT & 撮初から & $1990 \sim$ & 最初から & 1972 & $\begin{array}{l}\text { 1970〜 } \\
\text { 最新収録 } \\
\text { まで }\end{array}$ & LT & 1994 & $2001 \sim$ & なし & 1994 & \\
\hline $\mathrm{AU}$ & $1973 \sim$ & なし & なし & $1973 \sim$ & $\begin{array}{l}1973 \sim \\
\text { 最新収録 } \\
\text { まで }\end{array}$ & LU & $1960 \sim$ & なし & 1945 & $1973 \sim$ & $1946 \sim$ \\
\hline $\mathrm{BA}$ & 1998 & なし & 1998 & 1998 & & $L V$ & 1994 & 1999 & なし & 1994 & \\
\hline $\mathrm{BE}$ & $1964 \sim$ & $1990 \sim$ & $1920 \sim$ & $1970 \sim$ & $1926 \sim$ & $M C$ & 1975 & なし & 最初から & 1958 & 最初から \\
\hline$B G$ & 1973 & $2000 \sim$ & 1993 & $1973 \sim$ & & MD & 1994 & $2000 \sim$ & なし & 1994 & \\
\hline$B R$ & $1974 \sim$ & なし & なし & 1975 & & MN & $\begin{array}{l}1972 \sim \\
1989 \\
\end{array}$ & なし & なし & $1973 \sim$ & \\
\hline $\mathrm{CA}$ & $1970 \sim$ & なし & $\begin{array}{l}1915 \text { 〜最新 } \\
\text { 収録まで }\end{array}$ & $1979 \sim$ & $\begin{array}{l}1970 \text { 〜 } \\
\text { 最新収録 } \\
\text { まで }\end{array}$ & MT & $\begin{array}{l}1967 \sim \\
1992\end{array}$ & なし & なし & なし & \\
\hline $\mathrm{CH}$ & 最初から & $1970 \sim$ & 最初から & 1965 & $1920 \sim$ & MW & $\begin{array}{l}1973 \sim \\
1994 \\
\end{array}$ & なし & なし & 1973 & \\
\hline $\mathrm{CN}$ & 1985 & $1990 \sim$ & なし & $1986 \sim$ & & $\mathrm{MX}$ & $\begin{array}{l}1981 \sim \\
1994\end{array}$ & なし & なし & $1981 \sim$ & \\
\hline cs & $\begin{array}{l}1973 \sim \\
1992 \\
\end{array}$ & なし & なし & $1973 \sim$ & & MY & $\begin{array}{l}1953 \sim \\
1996 \\
\end{array}$ & なし & なし & 1953 & \\
\hline $\mathrm{cu}$ & $\begin{array}{l}1974 \sim \\
1975 \\
\end{array}$ & なし & なし & $1974 \sim$ & & $\mathrm{NL}$ & $1964 \sim$ & $1990 \sim$ & 取初から & $1964 \sim$ & 最初から \\
\hline $\mathrm{CY}$ & $1975 \sim$ & なし & 1998 & 1975 & & NO & 1973 & なし & なし & 1973 & \\
\hline $\mathrm{CZ}$ & $1993 \sim$ & $2000 \sim$ & なし & $1993 \sim$ & & $\mathrm{NZ}$ & \begin{tabular}{|l|}
$1978 \sim$ \\
1999 \\
\end{tabular} & 1999 & なし & $1984 \sim$ & \\
\hline $\mathrm{DD}$ & 1973 & なし & 最初から & 1973 & & $\mathrm{OA}$ & $1966 \sim$ & なし & 最初から & $1966 \sim$ & \\
\hline $\mathrm{DE}$ & $\begin{array}{l}A-C 1920 \\
\sim\end{array}$ & $1970 \sim$ & 最初から & $1972 \sim$ & 最初から & $\mathrm{PH}$ & $\begin{array}{l}1975 \sim \\
1997 \\
\end{array}$ & なし & なし & 1975 & \\
\hline DEU & $1973 \sim$ & なし & 1929 & 1973 & 1985 & $\mathrm{PL}$ & 1973 & なし & なし & 1973 & \\
\hline DK & $1920 \sim$ & $1990 \sim$ & $1920 \sim$ & $1969 \sim$ & & $\mathrm{PT}$ & 1976 & $1990 \sim$ & $1980 \sim$ & $1976 \sim$ & \\
\hline $\mathrm{EA}$ & $1996 \sim$ & なし & なし & 1996 & & $\mathrm{RO}$ & $1973 \sim$ & 1999 & 1973 & 1973 & \\
\hline $\mathrm{EE}$ & 1995 & なし & 1995 & 1995 & & $\mathrm{RU}$ & 1993 & 1998 & なL & 1993 & \\
\hline$E G$ & $1976 \sim$ & なL & なし & $1976 \sim$ & & $\mathrm{SE}$ & 1973 & $1990 \sim$ & $1920 \sim$ & $1968 \sim$ & \\
\hline EP & 最初から & 最初から & 最初から & 最初から & 最初から & $S G$ & 1983 & なし & なL & 1983 & \\
\hline ES & $1968 \sim$ & \begin{tabular}{|l|}
$1983 \sim$ \\
\end{tabular} & $1964 \sim$ & 1968 & & SI & 1992 & 1998 & なし & 1992 & \\
\hline $\mathrm{FI}$ & 1975 & 1985 & $1920 \sim$ & $1969 \sim$ & & SK & 1993 & 1993 & SL & $1993 \sim$ & \\
\hline FR & $1920 \sim$ & $1970 \sim$ & $1920 \sim$ & $1969 \sim$ & $1902 \sim$ & su & $\begin{array}{l}1972 \sim \\
1992 \\
\end{array}$ & 1998 & $1970 \sim 1994$ & $1972 \sim$ & \\
\hline GB & $1920 \sim$ & $1970 \sim$ & $1920 \sim$ & $1973 \sim$ & $1909 \sim$ & $T J$ & 1998 & なし & なし & 1998 & \\
\hline GR & $1977 \sim$ & $1996 \sim$ & 1976 & 1978 & & $\overline{T R}$ & 1973 & \$L & なL & $1976 \sim$ & \\
\hline HK & $1976 \sim$ & なし & なし & 1976 & & TW & 1983 & $2000 \sim$ & なし & $2000 \sim$ & \\
\hline HR & 1994 & なし & なL & 1994 & & US & $1920 \sim$ & $1970 \sim$ & $1836 \sim$ & 1969 & $1920 \sim$ \\
\hline IE & $1930 \sim$ & $1990 \sim$ & $1929 \sim$ & $1930 \sim$ & & VN & $\begin{array}{l}1984 \sim \\
1997 \\
\end{array}$ & なし & なL & $1984 \sim$ & \\
\hline IL & $1968 \sim$ & なし & なし & $1968 \sim$ & & WO & $1978 \sim$ & 1978 & 1978 & 最初から & 最初から \\
\hline IN & $1975 \sim$ & なし & なし & $1975 \sim$ & & YU & $\begin{array}{l}1973 \sim \\
1986 \\
\end{array}$ & なし & なし & $1973 \sim$ & \\
\hline IT & 1973 & 1993 & 1985 & 1973 & & ZA & $1971 \sim$ & なL & なし & $1971 \sim$ & \\
\hline $\mathrm{JP}$ & $\begin{array}{l}\text { A-C } 1973 \\
\sim\end{array}$ & $1973 \sim$ & $1920 \sim$ & $1973 \sim$ & & $Z M$ & $\begin{array}{l}1968 \sim \\
1994\end{array}$ & なし & なし & $1969 \sim$ & \\
\hline & & & & & & $Z W$ & $\begin{array}{l}1980 \sim \\
1993 \\
\end{array}$ & なし & なし & $1980 \sim$ & \\
\hline
\end{tabular}

(9) 終了ページ

ここに掲載されている学術文献とは国際調査機 関によって合意されたPCTリストに基づく非特許 文献（PCT規則 34.1（b）(iii)）。

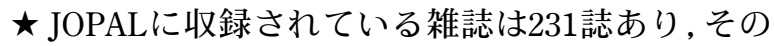
一覧を（資料1）として添付する。
図2で検索結果の丸で囲っているIPCの部分から， 図3の同一IPCを持つ特許の一覧へリンクが張られ ている。

さらに,この一覧をクリックすると書誌と抄録 と代表図面が表示され, そこから全文公報を閲覧 することも可能である。 


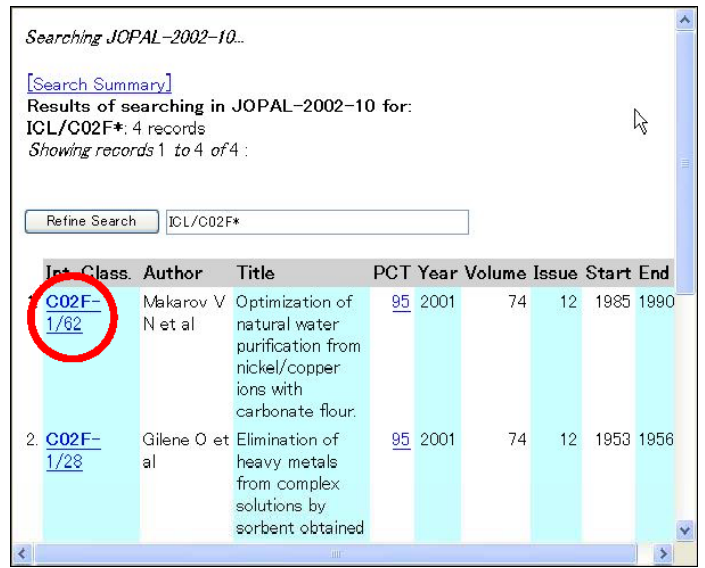

図2 JOPAL検索結果（雑誌）WIPOより

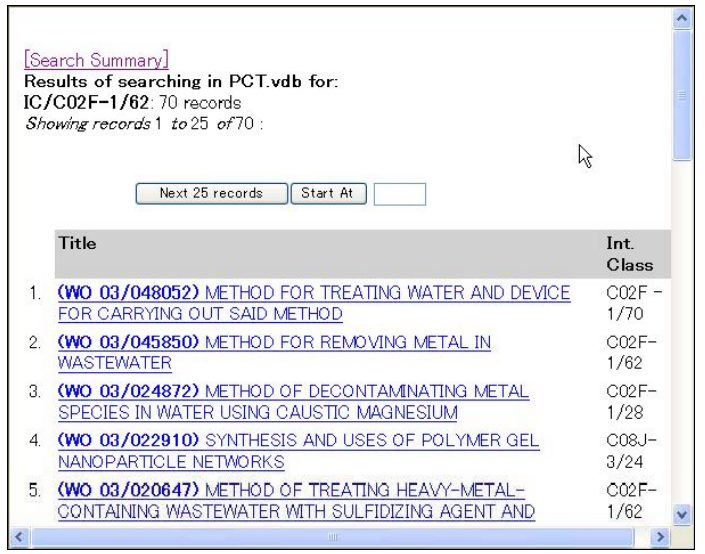

図3 JOPAL検索結果（特許）WIPOより

このように, IPCを検索キーとして, 雑誌と特許 双方を検索することが可能となっているデータベー スは現在はJOPALのみである。

図4の上部の丸の部分から請求項や発明の詳細テ キストおよび公報イメージへのリンクがある。

また, 中ほどの丸からは, PCT出願の場合指定 した各国への移行期間が国ごとに違うので，国別 の移行期間一覧表へとリンクがある。

WIPOはJOPAL以外にもさまざまな試みをしてい る。そのひとつは全文検索データベースである。

現在, 米国特許庁では自国の特許の全文検索が 可能であるが，それ以外の国では，まだ全文検索 が無料で使えるデータベースの提供はなかったが 今回の試みにより, WIPOでPCT出願された特許の 全文検索が可能になるということは多数の国々で の全文検索が可能になったような効果をもたらす と思われる。現在, プロトタイプということもあ り,収録期間は少なく,2003年1月からである(図6)。

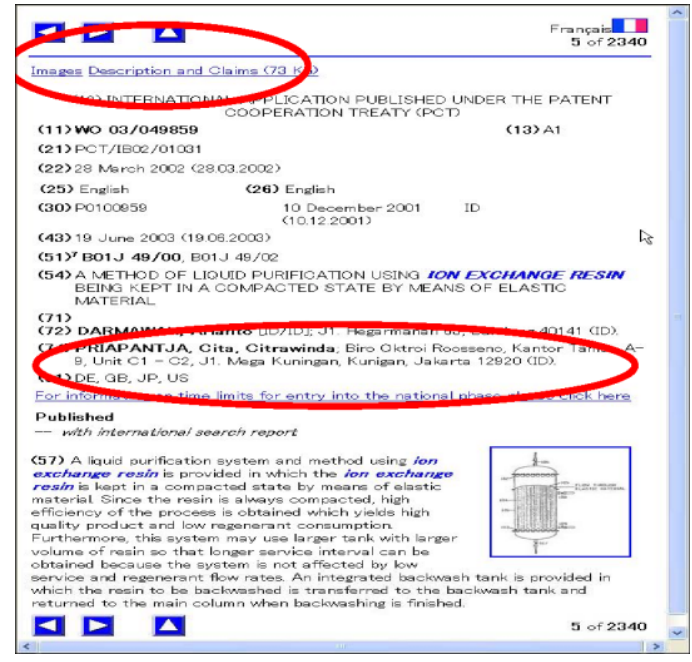

図4 JOPAL書誌/抄録/代表図面 WIPOより

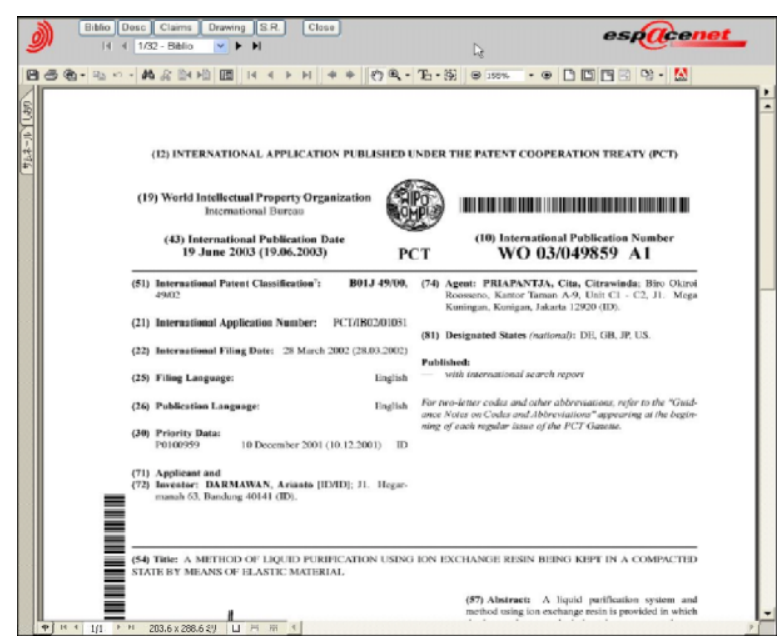

図5 JOPAL 公報 WIPOより

図6の収録内容は以下のとおり

検索対象データ : 「Front Page $」$ or $「$ Full Text $」$

口ソート順 : 年代順 関連度順

—期間：2003年1月から週ごとに

ロ検索タグ : 左側

(1) 英語とフランス語のタイトル

(2) 英語とフランス語の抄録

(3) 公報番号

(4) 公報日

(5) 出願番号

(6) 出願日

(7) 優先権番号

(8) 優先権主張日

(9) 優先権国

（10）公報種別 


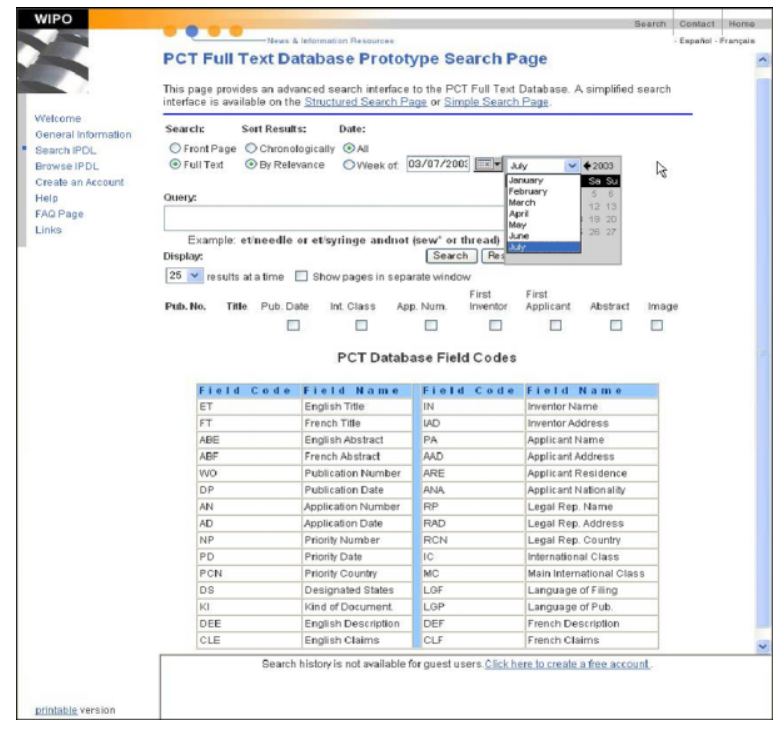

図6 全文検索DB（プロトタイプ）WIPOより
(11) 英語での記載
(12) 英語で書かれた特許請求範囲

検索タグ : 右側

(1) 発明者名

(2) 発明者住所

(3) 出願人名

(4) 出願人住所

(5) 出願人の法定住所

(6) 出願人国

(7) 法定代理人の名前

(8) 法定代理人住所

(9) 法定代理人国

(10) IPC

(11) 筆頭IPC

(12) ファイリング言語

(13) 公の言語

(14) フランス語での記載

(15) フランス語で書かれた特許請求範囲

表示数 10，25，50（デフォルト25）

口 表示方法で新しい空を開くかどうかの選択

口検索結果一覧での表示項目

公報番号 IPC 出願番号 第一発明者 第一出願人 抄録 代表図面

ネ公報イメージまで取得可能

ネ検索コマンドはJOPALと同一 その他にも有用な医製薬に関する期限切れの特 許をインド政府が収集し， CD－ROMを作成した。 それをWIPOへ提供したことにより，できたデー タベースが「Health Heritage Test Database」である。

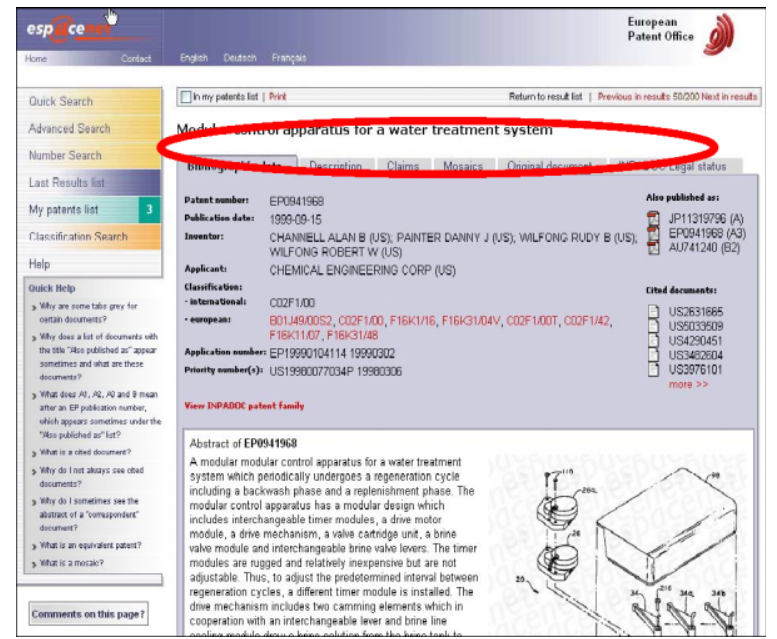

図7 esp@ cenet version3 EPOより

また,ヨーロッパ特許庁ではINPADOC (INternational PAtent DOcumentation Center) の権利状況情報やパテ ントファミリー情報のすべてを無料で搭載した 「esp@cenet version3」の提供サービスを始めた。こ のことにより今まで商用データベースを経由して 利用していたINPADOCの内容が無料で使えるよう になった（図7）。

図7の丸部分に各種表示タグがあり画面の切り替 えができるようになっている。

画面切り替えによる表示項目は(1)〜(13)までで ある。

(1) 発明の名称

(2) 公報番号

(3) 公報日

(4) 発明者

(5) 出願人

(6) 分類 IPC とECLA

(7) 出願番号

(8) 公報番号

(9) 対応特許（公報へリンクあり） パテントファミリー一覧へのリンクもある

(10) 引用特許（公報ヘリンクあり）

(11) 抄録（請求項 発明の詳細）

(12) 代表図面（すべての図面）

(13) INPADOCの権利状況全情報

ネ esp@cenet version3ではMy Patent Listとして選択 した特許20件を 30 日間登録できる。

さらにヨーロッパ特許庁では紙包袋を電子化し， 電子包袋として「epoline Online File Inspection」の サービスを開始した。ヨーロッパ特許庁は過去へ 遡及してすべての包袋を電子化するとしているこ 


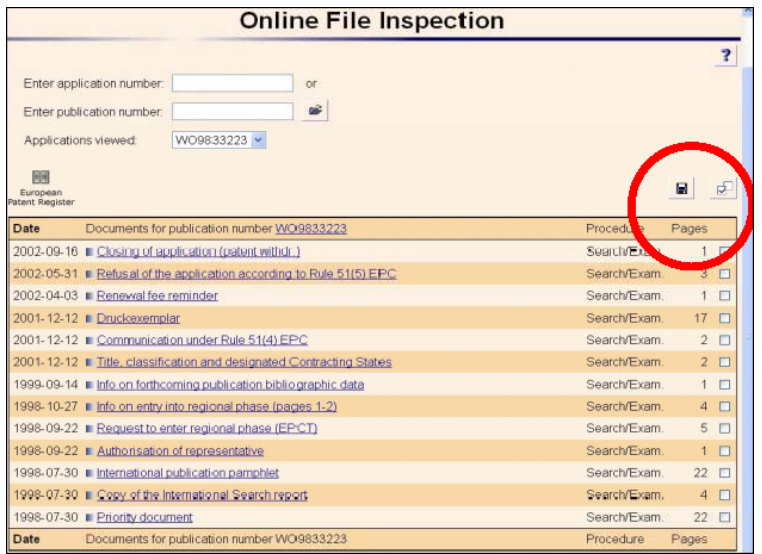

図8 epoline Online File Inspection EPOより

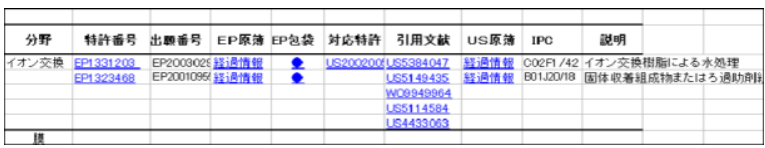

図9 社内外国特許管理 My Database

とが興味深い。しかも包袋に非特許文献があれば, それも電子化するとも報知している。

電子化できたものから順次公開される予定であ る。また著作権についてもクリア済みとしている。 しかも, これらの電子情報はPDF化して, 包袋中 の個別の書類としても，包袋をすべて一括として も，図8の丸で示した個所からダウンロードでき る。一括ダウンロードしたPDFには索引情報もつ いているので, 中の書類を整理し直す手間も省け る。また, この電子包袋と原簿（経過情報）とは 相互リンクされており, どちらからでも検索可能 である(図8)。

これら情報を活用して自社の外国出願の分厚い 紙資料をすべて電子包袋とすれば，保存スペース の節約ばかりか, 情報の共有化, さらには簡単に データベース化も可能となろう。

また，ヨーロッパ特許庁では非特許文献にヨー ロッパ特許分類のECLAを付与し, それらの検索 サービスを開始する用意があるとアナウンスして いる。このように各国特許庁の成熟速度は非常に 速く，しかも質の良い情報が無料で提供されるの で,これらの活用は企業にとってもかなり価值が あると思われる（図9）。

\section{5. 韓国・台湾の無料DBの最新活用法}

韓国, 台湾から提供される特許情報データベー

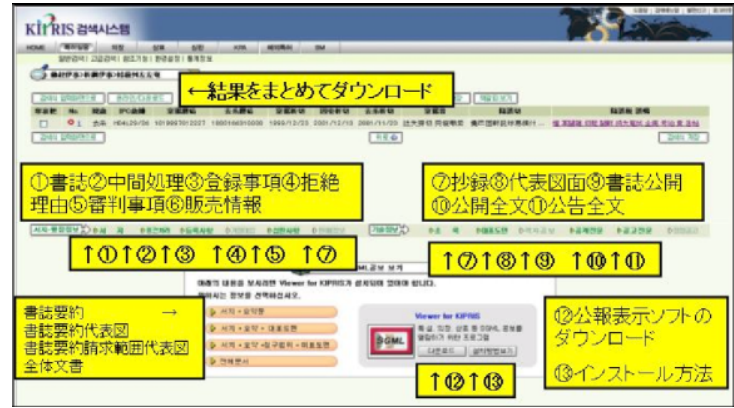

図10 韓国特許情報院より

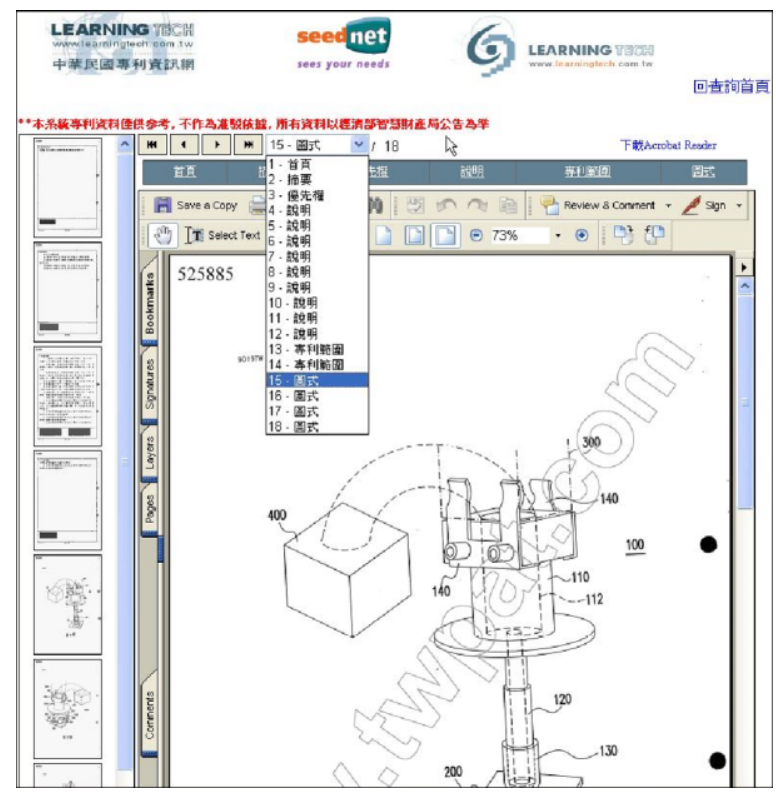

図11 中華民国専利資訊網より

スの動向には感銘することが多々ある。

まず，韓国では韓国特許情報院（韓国特許庁の 外郭団体) から無料で全文公報および検索結果デー タのダウンロードが提供されるとともに, 詳細な 経過情報なども閲覧できるようになった（図10）。

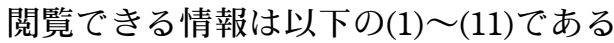

(1) 書誌 (2) 中間処理 (3) 登録事項 (4) 拒絶理由

（5）審判事項 （6) 販売情報 （7）抄録 （8）代表図面

(9) 書誌公開 (10) 公開全文 (11) 公告全文

ただし,公報を表示するにはSGML表示用ソフト をダウンロードする必要がある。

また, csv形式にてダウンロードできる情報の組

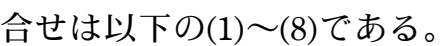

（1）番号対照表 （2）概略表示 （3）書誌表示 （4）書 誌中間処理 （5）書誌登録情報 (6) 書誌, 審判情報 （7）書誌, 抄録情報 (8) 書誌, 中間処理, 登録, 審 判情報 


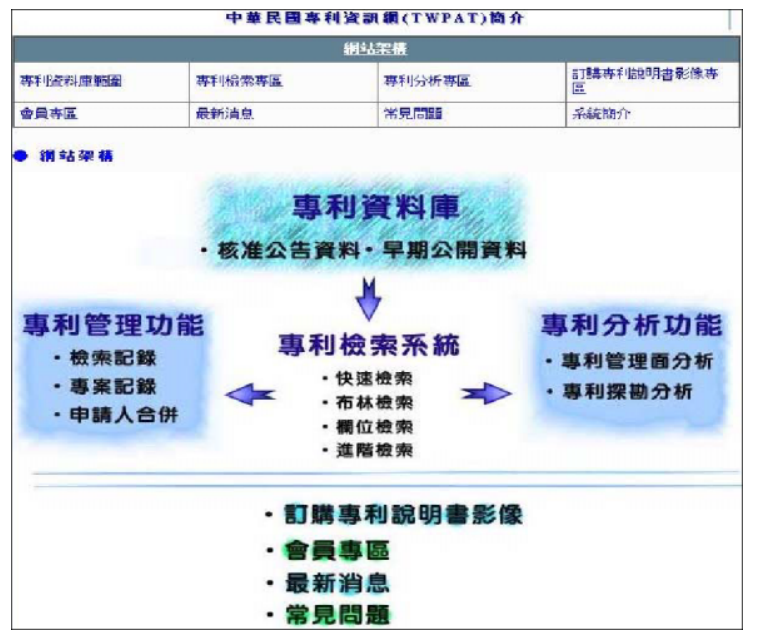

図12 中華民国専利資訊網より

これらの情報はTAR32という圧縮形式でダウン ロードされるので, この場合解凍ソフトが必要で ある。

ソフト取得サイトのアドレスは下記のとおりで ある。

（http://www.csdinc.co.jp/archiver/lib/tar32.html）

さらに台湾特許庁でも無料で全文の公告説明書 が閲覧できるようになった（図11）。

台湾特許庁では2001年10月26日の特許法の改正 を受けて今までなかった早期公開制度と審査請求 制度が2002年10月26日から施行されるようになっ た。

また, 全文検索等の検索方式の種類も増えて, ユーザが検索しやすくなった。また, 台湾の身分 証明書所持者は有料会員となる事で, さらに特許 分析を可能とするツールやウォッチングサービス 等も受けることができる。身分証のある無料試用 会員でも対価を支払うことで, 公報の一括ダウン ロードができる（図12）。

\section{6. その他の無料データベースの活用法}

日本において非特許文献調査といえば，科学技 術振興機構が提供する「JOIS」であり，この活用 については周知であるが, 科学技術振興機構はそ れ以外にも無料で有用なデータベースをいくつも 提供している。そのいくつかは先行技術調査に使 える。

例えば「研究開発支援総合ディレクトリ ReaD」 である。このデータベースは, 日本の公的機関お よび協力企業などによる研究開発に関する情報を,

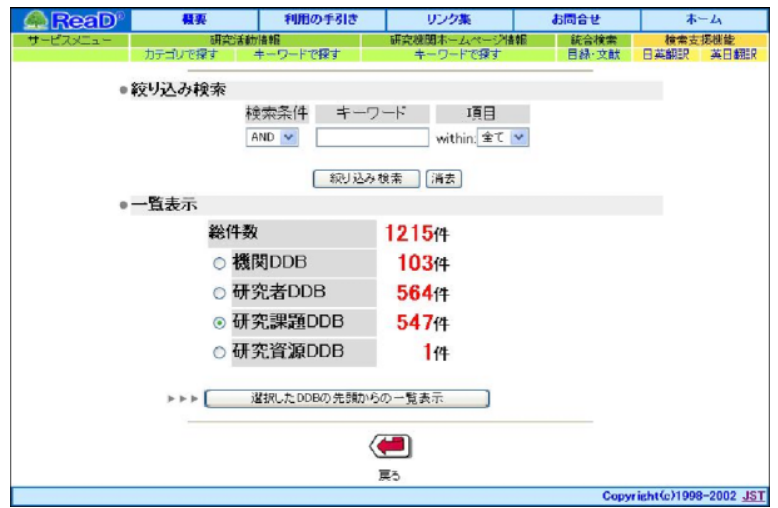

図13 ReaDの検索画面 JSTより

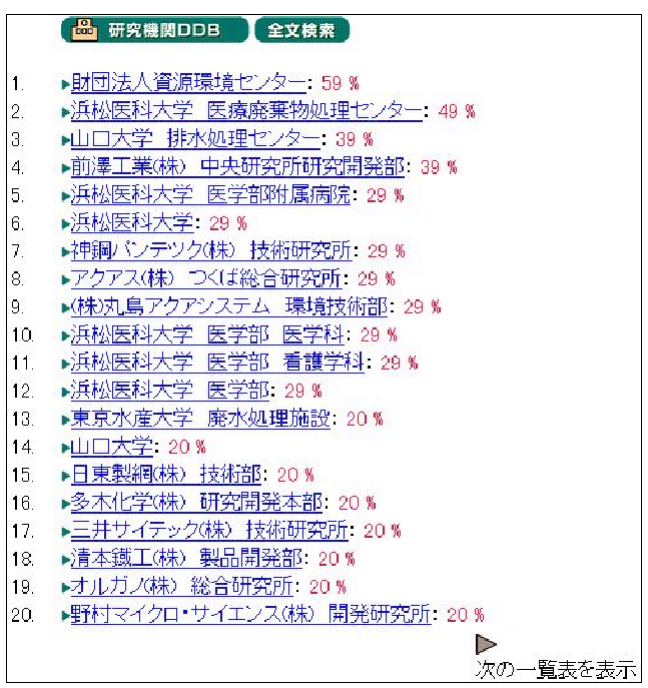

図14 ReaDの検索結果 JSTより

研究機関, 研究者, 研究課題, 研究資源の4項目に ついて収録しており, キーワードから検索できる。 自社と関連ある研究を行っている機関, 企業, 研 究者, 研究内容等がわかるのでそれらを検索キー として, 先行技術調査における特許および非特許 文献調査ができる。

これらの情報は, 最先端の研究であるからこそ 特許に一番近いのではないかと思う（図13,14,15）。

図13の検索画面では検索結果すべての件数が表 示され, その中をさらに絞り込んだり, また表示 したいものを選択して一覧表示させることができ る。

図14は「水処理」というキーワードで検索した 結果の中から「研究機関」の一部を表示したもの である。確かに公的研究機関以外にも関連する企 業名がヒットしている。このデータベースでは, 誰がどのような研究を行っているかを見ることも 


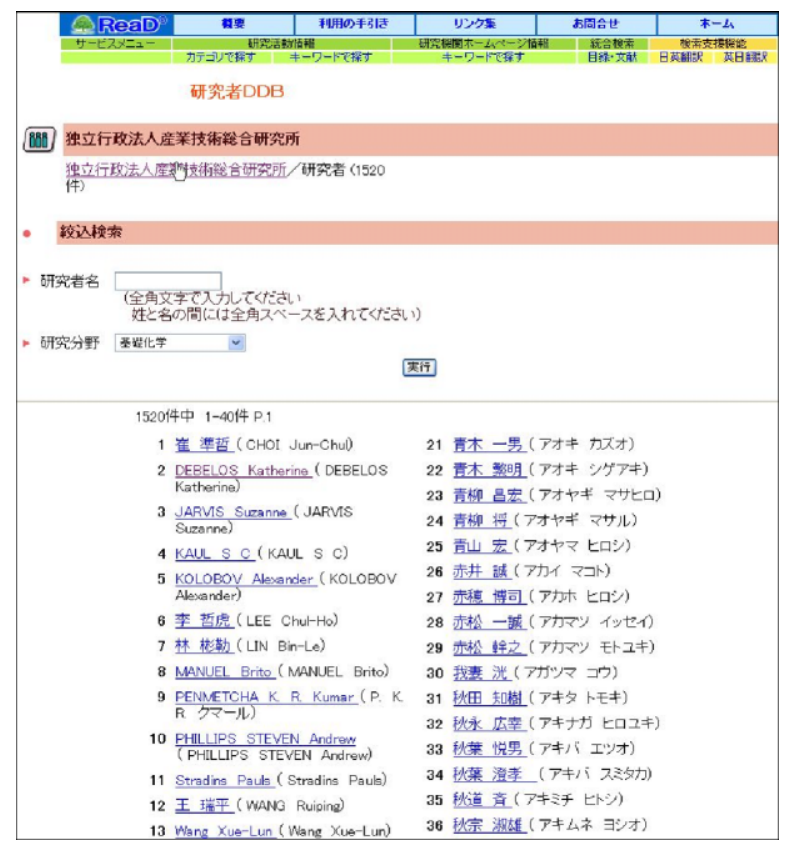

図15 ReaDの検索画面 JSTより

可能である。これらの情報から企業名や発明者ま たは著者名, さらに研究内容をつかみ，それらを 使って特許や非特許文献データベース等で調査す ることで調査範囲を絞りこんだり，予想していな かった部分の補充をしたり等, さまざまな使い方
ができる。

特にアメリカは出願人名でなく発明者名での出 願が多いので, 研究者名等を事前に知ることが重 要である。Readの中には日本の研究機関に在籍す る外国人研究者も多く掲載されている（図15）。

\section{まとめ}

世界中, 誰もがどこからでも情報発信が可能と なった今日, 調査範囲の拡大に伴う新たな調査方 法が必要となってきていると思う。調査には, 特 許情報のSDIのみならず, 自己のスキルアップのた めのSDI, すなわち「最新の特許調査方法に関する 情報」のSDIも心がけ, 自らを常に活性化させてお く必要があると痛感している。また, 2004年4月か らは審査請求料が倍額となる。倍額にもかかわら ず企業が審査請求する特許は企業として特許権の 取得を強く望んでいるものだと思われる。新時代 の審査官による先行技術調査に呼応し, それ以上 の調査を行うことで審査をスムーズにし, 早期権 利化を図る事は「知財立社」へもつながることと 思う。横溢する情報の中, さまざまなデータベー スの活用法や調査方法に日々新たな発見があり， 拙著者としては自脳や「DB航海士」の更新に忙し い毎日である。 


\section{資料1 JOPAL収録雑誌一覧}

\begin{tabular}{|c|c|c|c|c|c|}
\hline 1 & Journal of the Acoustical Society of America & & $\begin{array}{l}\text { IEEE-Transactions on Ultrasonics, Ferroelectrics and } \\
\text { Frequency Control }\end{array}$ & 161 & TPI Textil Praxis International \\
\hline 2 & Journal of the Acoustical Society of Japan & 82 & Industrial and Engineering Chemistry - Fundamentals & 162 & Textlle Manufacturer and Knitting World \\
\hline 3 & Acta Chemica Scandinavica & 83 & $\begin{array}{l}\text { Industrial and Engineering Chemistry Research: Process } \\
\text { Design and Development }\end{array}$ & 163 & Textle Research Journal \\
\hline 4 & Spray Technology \& Marketing & 84 & $\begin{array}{l}\text { Industrial and Engineering Chemistry: Product Research and } \\
\text { Development }\end{array}$ & 164 & VDI-Z / Zeitschrift tür Integrierte Produktionstechnik \\
\hline 5 & Bioscience, Biotechnology and Biochemistry & 85 & $\begin{array}{l}\text { Transactions of the Institute of Electronics, Information and } \\
\text { Communication Engineers }\end{array}$ & 165 & Journal of the Water Pollutition Control Federation \\
\hline 6 & Agricultural Machinery Journal & 86 & \begin{tabular}{|l|}
$\begin{array}{l}\text { International Polymer Science and Technology [Soviet Rubber } \\
\text { Technologyl] }\end{array}$ \\
\end{tabular} & 166 & Westinghouse Engineer \\
\hline 7 & Journal of the American Ceramic Society & 87 & Nachrichten Elektronik und Telematik & 167 & Wiggin Nickel Alloys \\
\hline 8 & Journal of the American Chemical Society & 88 & Iron and Steel International & 168 & Electronics and Wireless World \\
\hline 9 & American Dyestuff Reporter & 89 & Journal of the Iron and Steel Institute of Japan & 169 & Chemical Abstracts \\
\hline 10 & Analytical Chernistry & 90 & Japanese Journal of Applied Physics & 170 & Bul etetin de la Sociétéé chimique de France \\
\hline 11 & Angewandte Chemie (IIternational Edition) & 91 & Kobunshi Ronbunshu & 171 & L'Onde éectrique \\
\hline 12 & Annals of Nuclear Energy & 92 & Journal of Agricultural and Food Chemistry & 172 & Automatic Control and Computer Science \\
\hline 13 & Applied Optics & 93 & Journal of Analytical Chemistry & 173 & Coke and Chemistry - Russian Federation \\
\hline 14 & Applied Physics Letters & 94 & Journal of Chemical Technology and Biotechnology & 174 & Farbe und Lack \\
\hline 15 & ASEA Journal & 95 & Journal of Applied Chemistry of Russia & 175 & Fibre Chemistry \\
\hline 16 & TM Technisches Messen & $9 \hat{6}$ & Journal of Applied Physics & 176 & Instruments and Experimental Techniques \\
\hline 17 & ATZ Automobitechnische Zeitschrift & 97 & Journal of Applied Polymer Science & 177 & Journal of Crystal Growth \\
\hline 18 & Automatic Welding & 98 & Journal of Chromatography & 178 & Journal of Orgaric Chemistry of Russia \\
\hline 19 & Automation and Remote Control & 99 & 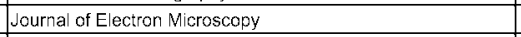 & 179 & Oil and Gas Journal \\
\hline 20 & Aviation Week and Space Technology & 100 & Journal of General Chemistry of Russia & 180 & Optics Communications \\
\hline 21 & AT\&T Bell Laboratories Record & 101 & Polyhedron & 181 & Radio Fernsehen Elektronik \\
\hline 22 & AT\&T Technical Journal & 102 & Journal of Metals & 182 & Solar Energy \\
\hline 23 & Brown-Boveri Review & 103 & The Journal of Organic Chemistry & 183 & Semiconductors \\
\hline 24 & Bulletin of the Academy of Sciences of the USSR: Physical Series & 104 & 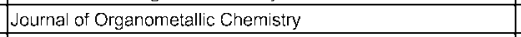 & 184 & Soviet Physics - Uspekhi \\
\hline 25 & Bulletin of the Academy of Sciences of the USSR: Chemical Series & 105 & Journal of Physics: Part B - Atomic and Molecular Physics & 185 & Technical Physics Letters \\
\hline 26 & Bulletin SEVNSE & 106 & Measurement Science \& Technology & 186 & Steel in translation \\
\hline 27 & Chemical \& Engineering News & 107 & Journal of Polymer Science & 187 & Telecommunications and Radio Engineering \\
\hline 28 & Chemical and Pharmaceutical Bulletin & 108 & Journal of the Royal Netherlands Chemical Society & 188 & Welding Production \\
\hline 29 & Chemical Engineering & 109 & Kautschuk \& Gummi Kunststoffe & 189 & Xerox Disclosure Journal \\
\hline 30 & Journal of Chemical Engineering of Japan & 110 & Kunststoffe & 190 & IEEE Transactions on Energy Conversion \\
\hline 31 & Chemical Reviews & 111 & Linde Reports of Science \& Technology & 191 & IEEE Transactions on Power Delivery \\
\hline 32 & Journal of the Chemical Society & 112 & Machine Design & 192 & IEEE Transactions on Power Systems \\
\hline 33 & Bulletin of the Chemical Society of Japan & 113 & Machinery and Production Engineering & 193 & AT\&T Technolog \\
\hline 34 & Journal of the Chemical Society of Japan & 114 & Machines and Tooling & 194 & Steel Times \\
\hline 35 & Chemie-Ingenieur-Technik & 115 & Measurement Techniques & 195 & Nature \\
\hline 36 & Journal für praktische Chemie & 116 & Melliande Textilberichte International Textile Repors & 196 & Proceedings of the National Academy of Sciences of the USA \\
\hline 37 & Chemische Berichte & 117 & Metal Finishing & 197 & Gene \\
\hline 38 & Chemistry and Industry & 118 & Metal Science and Heat Treatment & 198 & Nucleic Acids Research \\
\hline 39 & CIAB-Geigy Review & 119 & Metallurgist & 199 & Science \\
\hline 40 & Civil Engineering & 120 & Metalworking Production & 200 & Welding International \\
\hline 41 & Collection of Czechoslovak Chemical Communications & 121 & Packaging & 201 & ABB Review \\
\hline 42 & Compressed Air & 122 & Modem Plastics International & 202 & Electronic Letters \\
\hline 43 & Comptes-rendus des Séances de l'Académie des Sciences & 123 & Nickel Topics & 203 & Computer Design \\
\hline 44 & Control and Instrumentation & 124 & NTZ & 204 & Elektronik \\
\hline 45 & Control Engineering & 125 & Nuclear Engineering International & 205 & IEEE Electron Device Letters \\
\hline 46 & Doklady - Chemistry & 126 & Journal of the Optical Society of America & 206 & Thin Solid Films \\
\hline 47 & Electrical Communication & 127 & Optics \& Spectrossopy & 207 & Wescon Techrical Papers \\
\hline 48 & Journal of the Electrochemical Society & 128 & Oyo Buturi & 208 & IEEE - Transactions on Nuclear Science \\
\hline 49 & Electronic Design & 129 & Philips Journal of Research & 209 & 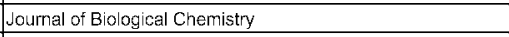 \\
\hline 50 & Electronic Engineering & 130 & Philips Technical Review & 210 & BBA Biochimica et Biophysica ACTA \\
\hline 51 & Electronics & 131 & Physical Review & 211 & Biochemistry \\
\hline 52 & E \& I Elektrotechnik und Maschinenbau & 132 & Plastverarbeiter & 212 & Cancer Research \\
\hline 53 & Engineering & 133 & Playthings & 213 & Methods in Enzymology \\
\hline 54 & Engineering Materials and Design & 134 & Polymer Science & 214 & Biochemical and Biophysical Research Communications \\
\hline 55 & ETZ (Elektrotechnische Zeitschrift) & 135 & Power & 215 & Clinical Chemistry \\
\hline 56 & Fördern und Heben & 136 & Power Farming & 216 & Journal of Immunology \\
\hline 57 & Funkschau & 137 & Soviet Journal of Communications Technology and Electronics & 217 & Embo Journal \\
\hline 58 & Giesserei & 138 & RCA Review & $2 \uparrow 8$ & Cell \\
\hline 59 & Glass and Ceramics & 139 & Review of Scientific Instruments & 219 & Popular Science \\
\hline 60 & Glastechnische Eerichte & 140 & AT Automatisierungstechnik & 220 & Popular Mechanics \\
\hline 61 & Heating, Piping \& Air Conditioning & 141 & Rubber Chemistry and Technology & 221 & Byte \\
\hline 62 & IBM Journal of Research and Development & 142 & Russian Chemical Reviews & 222 & BiofTechnology \\
\hline 63 & IBM Technical Disclosure Bulletin & 143 & Soviet Engineering Research & 223 & Plant Physiology \\
\hline 64 & IEEE Journal of Quantum Electronics & 144 & \begin{tabular}{|l|l} 
Automotive Engineering \\
\end{tabular} & 224 & Technische Rundschau \\
\hline 65 & IEEE Journal of Solid State Circuits & 145 & Scientific American & 225 & Messen und Prüfen \\
\hline 66 & Proceedings of the IEEE & 146 & Siemens Review & 226 & VDI-Nachrichten \\
\hline 67 & IEEE Spectrum & 147 & SMPTE Journal & 227 & Konstruktion \\
\hline 68 & |IEEE-Transactions on Aerospace and Electronic Systems & 148 & SDC Journal of the Society of Dyers and Colourists & 228 & Elektor \\
\hline 69 & IEEE-Transactions on Signal Processing & 149 & Solid-State Electronics & 229 & Biotechnology Abstracts \\
\hline 70 & IEEE-Transactions on Automatic Control & 150 & Solid-State Technology & 230 & $\begin{array}{l}\text { EDN (Electronic Technology for Engineers and Engineering } \\
\text { Managers) }\end{array}$ \\
\hline 71 & |IEEE-Transactions on Biomedical Engineering & 151 & Soviet Atomic Energy & 231 & Bell tabs Technical Journal \\
\hline 72 & IEEE-Transactions on Consumer Electronics & 152 & Soviet Physics - Acoustics & & \\
\hline 73 & |EEE-Transactions on Communications & 153 & Soviet Physics - Doklady & & \\
\hline 74 & IEEE-Transactions on Computers & 154 & Soviet Physics - Solid State & & \\
\hline 75 & |EEE-Transactions on Electron Devices & 155 & Soviet Physics - Technical Physics & & \\
\hline 76 & IEEE-Transactions on Geoscience and Remote Sensing & 156 & Stahl und Eisen & & \\
\hline 77 & IEEE-Transactions on Instrumentation and Measurement & 157 & Steroids: Structure, Function and Regulation & & \\
\hline 78 & IEEE-Transactions on Microwave Theory and Techriques & 158 & TAPP: Journal & & \\
\hline 79 & $\begin{array}{l}\text { IEEE-Transactions on Components, Hybrids and Manufacturing } \\
\text { Technology }\end{array}$ & 159 & Tetrahedron & & \\
\hline 80 & |EEEE-Transactions on Power Apparatus and Systems & 160 & Tetrahedron Letters & & \\
\hline
\end{tabular}

